\title{
Rapid Shoot Regeneration from Thin Cell Layer Explants of an Endangered Medicinal Asclepiad Ceropegia spiralis L.
}

\author{
K. Sri Rama Murthy* and R. Kondamudi \\ School of Conservation Biology and Plant Biotechnology, Department of Biotechnology, \\ Montessori Mahila Kalasala, Vijayawada - 520 010, Andhra Pradesh, India
}

Key words: Ceropegia spiralis, Thin cell layer explants, Recalcitrants, Regeneration

\begin{abstract}
The thin cell layers of nodes and internodes of Ceropegia spiralis L. were cultured on MS supplemented with BAP $13.32 \mu \mathrm{M} / 1+\mathrm{NAA} 0.537 \mu \mathrm{M} / 1$ induced $17.34 \pm$ 0.55 shoots showing extensive growth. Later on the organogenesis was also induced on MS containing BAP $13.32 \mu \mathrm{M} / 1+2$, 4-D $1.130 \mu \mathrm{M} / \mathrm{l}$, whereas the medium with BAP $13.32 \mu \mathrm{M} / 1+2$, 4-D $4.52 \mu \mathrm{M} / 1$ has the highest callus producing ability in recalcitrants as well as in normal explants. Shoots developed were rooted best on $0.5 \mathrm{MS}$ with NAA $10.74 \mu \mathrm{M} / \mathrm{l}$. Optimum shoot and root multiplication was obtained within eight weeks. In vitro plantlets were successfully weaned and transferred to soil with about 90 per cent survival rate. So far, more than 650 weanlings have been produced successfully and reintroduced into nature for their recovery.
\end{abstract}

\section{Introduction}

The genus Ceropegia (Asclepiadaceae) was reported by 200 species distributed in the tropical and subtropical Asia, Africa, Australia, Malaysia and in the Canary and Pacific islands (Bruyns 2003). In India $48 \mathrm{spp}$. were found of which 28 are endemic to the Peninsular India (Ansari 1984, Ahmedullah and Nayar 1986). Ceropegia spiralis L. an annual herb grown wildly in south India is an endangered species (Nayar and Sastry 1987, Madhav Gadgil 2004) popularly known to villagers, herbalists, as "Nimmati gadda". A slender erect or slightly twining herb up to $50 \mathrm{~cm}$ long, with depressed tubers. Flowering and fruiting are in between May and October months.

Tuberous roots of many Ceropegia species are edible. The root tubers are the officinal parts contain an alkaloid called "Ceropegin" (Nadkarni 1976) bitterness of the tubers was eliminated by boiling and then consumed (Mabberley 1987).

*Corresponding author. <drksrmurthy@yahoo.com>. 
The Ceropegia spiralis root tubers are also known to contain starch, sugars, gum, albuminoids, fats, crude fiber and valuable constituents which are used in many traditional Indian Ayurvedic drug preparations active against many diseases especially diarrhoea, dysentery. The starchy tubers are useful as a nutritive tonic (Kirtikar and Basu 1935, Reddy et al. 2006, Chopra et al. 1956). In this genus C. bulbosa and C. candelabrum also have medicinal properties (Jain and Defillips 1991). Several reports were published on the in vitro studies of Ceropegia species i.e., C. candelabrum (Beena and Martin 2003, Beena et al. 2003), C. bulbosa var. bulbosa (Britto et al. 2003). C. bulbosa (Goyal and Bhadauria 2006) C. jainii, C. bulbosa. C. bulbosa var. lushii (Patil 1998), C. sahyadrica (Nikam and Savant 2007). However, to date, there are no reports on the micropropagation of $C$. spiralis though it is an important edible tuberous asclepiad in the Southern Peninsular India. The aim of the present investigation was to develop systems for in vitro propagation to conserve and domesticate the wild endemic taxa C. spiralis.

Present investigation describes a shoot regeneration system using transversal thin cell layer (tTCLs) isolated from the C. spiralis. The TCL technology originated long ago. Since then, TCLs have been successfully used in the micropropagation of many plants including some recalcitrants such as Lupinus species (Mulin and Bellio-Spataru 2000) and Spinacea oleracia (Leguillon et al. 2003).

Cell divisions is a critical activity during the growth and development of a plant providing the building blocks for the differentiation of in vitro thin cell layers. Moreover, TCL technology is a solution to many of the issues currently hindering the efficient progress of medicinal, ornamental and floricultural crop improvement, since it addresses the issue of plant breeding at the first stage of the problem. Since the regeneration of specific organs may be effectively manipulated with TCLs, in conjunction with specific controlled in vitro conditions and exogenously applied plant growth regulators

\section{Materials and Methods}

An in vivo growing Ceropegia spiralis L. (Nimmati gadda) was collected from Akashaganga of Tirumala hills, Eastern Ghats, India. The voucher specimen KSM 14878 was deposited in the department of biotechnology herbarium, Montessori Mahila Kalasala, Vijayawada, Andhra Pradesh, India. The nodes containing axillary buds were washed in the running tap water followed by a fungicide and bactericide each $0.3 \%$ for $10 \mathrm{~min}$ and with tween $20(5 \% \mathrm{v} / \mathrm{v}$ for 4 min). Then with surface disinfectant $\mathrm{HgCl}_{2}(0.1 \% \mathrm{w} / \mathrm{v}$ for $2 \mathrm{~min})$ after repeated washes in double distilled water, the sterilized segments were then washed thoroughly with sterilized distilled water, cut into appropriate sizes, and cultured on MS solidified with agar $0.9 \%$ (w/v) HiMedia Laboratories Pvt. Ltd. 
Mumbai and different growth regulators (BAP, NAA, IAA, IBA) at different concentrations either alone or in combinations were added to the medium. In the present investigation all the media were autoclaved at $121^{\circ} \mathrm{C}$ and $15 \mathrm{lbs}$ pressure for $20 \mathrm{~min}$ after adjustment of the $\mathrm{pH}$ to $5.7 \pm 1$. However, in present study, TCL explants were excised transversely from in vitro grown six months old plants.

All the cultures were maintained at $24 \pm 2^{\circ} \mathrm{C}$ under $16 \mathrm{hrs}$ photoperiod with 3000 lux light intensity using fluorescent lights (Philips India Ltd.) and 90 - 95\% relative humidity within $250 \mathrm{ml}$ Bottles and $25 \times 150 \mathrm{~mm}$ culture tubes and the test tubes were covered with the aluminum foil. When the hormones failed to induce a specific response (callus, adventitious shoots/roots) at the end of the first cycle, it was not considered as suitable combination. Twenty cultures were raised for each treatment and all experiments were repeated thrice.

Explants (tTCLs of 1-2 mm thickness) were excised from the nodal and internodal regions of in vitro grown plantlets were placed in contact with the medium. The explant showed an excellent response within a week. Both transverse TCLs and longitudinal TCLs were employed in the present investigation, the explants were excised from the nodal and internodal meristematic regions, four TCLs (two from each side) were taken from either sides of the node. Only tTCLs response is considerable. The sections of the explant were placed on the MS supplemented BAP in combination with different auxins to induce the callus, organogenesis and somatic embryos. The synthetic auxins IBA and NAA are quite active in induction of rooting. They were tested individually and in combination. IBA and NAA were induced and elongated the roots, respectively when they used in combination.

Microshoots with well-developed root system were transferred directly to small pots containing sterile vermiculite and coco peat in $(1: 1)$ ratio rejuvenated growth within 20 days. Survival rate of the plantlets is 90 per cent and plantlets successfully established in the field exhibited morphology similar to that of mother plants.

\section{Results and Discussion}

The TCL system is quite suitable for the regeneration of plantlets from the explants. With the help of this method, the problem created by the latex can be avoided in normal cultures. The TCLs contain less amount of latex in them, which facilitate the correct contact with the medium. In the current investigation, the shoot regeneration was noticed using tTCLs isolated from the nodal explants, the tTCLs explants were excised from in vitro grown plants swelled after four/five days of culture, due to small amount of light green callus proliferation on the sub epidermal area. Shoot regeneration occurred from tTCL explants that appeared green and formed a peripheral crown of buds which elongated rapidly 
within a week. The optimum number of shoots (17.34 \pm 0.55$)$ (Fig. 1B) were observed in the medium containing BAP $13.32 \mu \mathrm{M} / 1+\mathrm{NAA} 0.537 \mu \mathrm{M} / 1$ and showed maximum regeneration capacity by producing shoots within a week (Table 1). The TCLs showed remarkable response by producing light green callus

Table 1. Effect of BAP and auxins on hoot regeneration from Ceropegia spiralis thin cell layer.

\begin{tabular}{|c|c|c|c|c|c|c|c|}
\hline \multirow{2}{*}{$\begin{array}{l}\mathrm{BAP} \\
\mu \mathrm{M} / 1\end{array}$} & \multicolumn{4}{|c|}{ Auxins in $\mu \mathrm{M} / 1$} & \multirow{2}{*}{$\begin{array}{r}\text { No. of shoots } \\
(\text { Mean } \pm \text { SD) }\end{array}$} & \multirow{2}{*}{$\begin{array}{l}\text { Length of shoots } \\
\quad(\text { Mean } \pm \text { SD) }\end{array}$} & \multirow{2}{*}{$\begin{array}{c}\text { Basal } \\
\text { callusing }\end{array}$} \\
\hline & $2,4-\mathrm{D}$ & IAA & IBA & $\overline{\text { NAA }}$ & & & \\
\hline 13.32 & 0.452 & & & & $6.79 \pm 1.52^{c}$ & $4.50 \pm 0.18^{d}$ & ++++ \\
\hline 13.32 & 1.130 & & & & $11.35 \pm 2.56^{b}$ & $4.25 \pm 0.36^{\mathrm{d}}$ & ++++ \\
\hline 13.32 & 2.26 & & & & $6.42 \pm 0.57^{c}$ & $1.10 \pm 0.33^{d}$ & ++++ \\
\hline 13.32 & 4.52 & & & & $3.58 \pm 0.23^{d}$ & $1.28 \pm 0.33^{\mathrm{d}}$ & ++++ \\
\hline 13.32 & & 0.577 & & & $5.17 \pm 0.32^{d}$ & $11.90 \pm 0.84 \mathrm{~b}$ & +++ \\
\hline 13.32 & & 1.44 & & & $3.59 \pm 0.35^{\mathrm{d}}$ & $8.20 \pm 0.24^{c}$ & +++ \\
\hline 13.32 & & 2.88 & & & $5.89 \pm 0.35^{\mathrm{cd}}$ & $5.05 \pm 0.14^{c}$ & ++ \\
\hline 13.32 & & 5.77 & & & $7.01 \pm 0.53^{c}$ & $8.56 \pm 0.19^{b}$ & +++ \\
\hline 13.32 & & & 0.49 & & $2.04 \pm 0.3^{\mathrm{d}}$ & $0.59 \pm 0.18^{\mathrm{d}}$ & + \\
\hline 13.32 & & & 1.23 & & $5.56 \pm 0.58^{c}$ & $5.43 \pm 0.52^{c}$ & +++ \\
\hline 13.32 & & & 2.46 & & $6.05 \pm 0.57^{c}$ & $15.09 \pm 0.66^{a}$ & ++ \\
\hline 13.32 & & & 4.92 & & $10.50 \pm 0.62^{b}$ & $8.29 \pm 0.12^{b c}$ & + \\
\hline 13.32 & & & & 0.537 & $17.34 \pm 0.55^{\mathrm{a}}$ & $10.32 \pm 0.25^{b}$ & ++++ \\
\hline 13.32 & & & & 1.342 & $6.00 \pm 0.48^{c}$ & $9.87 \pm 0.50^{b}$ & +++ \\
\hline 13.32 & & & & 2.685 & $7.34 \pm 0.36^{c}$ & $6.53 \pm 0.14^{c}$ & +++ \\
\hline 13.32 & & & & 5.37 & $5.44 \pm 0.42^{\mathrm{d}}$ & $7.04 \pm 0.33^{c}$ & ++++ \\
\hline
\end{tabular}

Mean following by the same letter was not significantly different by Tukey test at $0.05 \%$ probability. Degree of callusing: $+=$ Very scanty; $++=$ Scanty $+++=$ Medium; $++++=$ Profuse.

which in turn gave a crown of shoots at its periphery. These results are comparable with studies on Ceropegia bulbosa (Raghuramulu and Pullaiah 1999), Cryptolepis buchanani (Venkateswara et al. 1987) of traditional explants (nodes, internodes, leaves) and from TCLs, in Brassica napus (Klimaszewska and Keller 1995); in Nicotiana tabaccum (Nhut et al. 2003a, Heylen and Vendrg 1991) based on these last two references using TCL explants provides a method for efficient bud regeneration. On the other hand, the medium containing BAP $13.32 \mu \mathrm{M} / 1+$ IBA $0.49 \mu \mathrm{M} / 1$ exhibited very low number of shoots (2) but they show an excellent rate of growth. The results stated that the BAP along with the NAA had a very good ability in induction of the shoots, all other auxins are inferior to the NAA in the vegetative bud differentiation. Well-developed shoots $(2-3 \mathrm{~cm})$ 
were inoculated on the different media containing auxins alone. Half strength of MS with 3\% sucrose supplemented with NAA $10.74 \mu \mathrm{M} / 1$ and $8.44 \pm 0.07$ (Fig. $1 \mathrm{C})$ the maximum root initiation $(85 \%)$ was observed. In vitro rooted plants were successfully weaned and transferred to mist chamber, after the acclimatization, the weanlings were transferred to soil with about 90 per cent survival rate (Fig. $1 \mathrm{E})$.
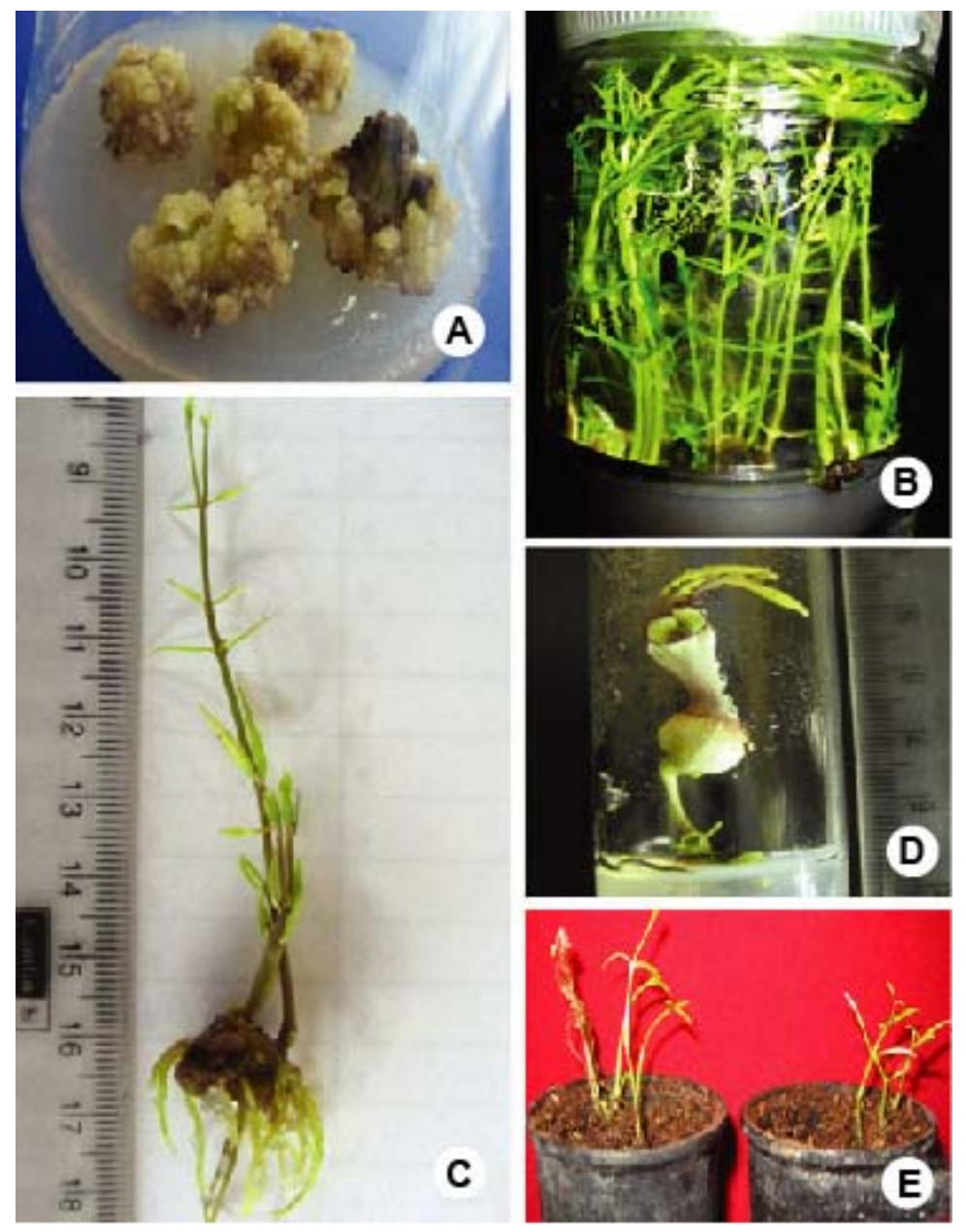

Fig. 1. Regeneration from thin cell layer explants of an endangered medicinal Asclepiad Ceropegia spiralis. A. Embryogenic callus development from the tTCLs cultured on MS fortified with BAP $13.32 \mu \mathrm{M} / 1+2,4-\mathrm{D} 1.103 \mu \mathrm{M} / 1$ after 30 days. B. Initiation of multiple shoots from the tTCLs on the medium containing BAP13.32 $\mu \mathrm{M} / 1+$ NAA $0.537 \mu \mathrm{M} / 1$ after 15 days. C. Rooting from in vitro raised shoots cultured on half strength of MS with $3 \%$ sucrose supplemented with NAA 10.74 $\mu \mathrm{M} / 1$ after 16 days. D. In vitro flowering from the tTCLs cultured on the medium supplemented with BAP $13.32 \mu \mathrm{M}+\mathrm{IAA} 5.77 \mu \mathrm{M} / 1$ showed enlarged flower after 7 days. E. Acclimatized plants after ten days. 
In the present investigation, tTCLs are quite active in callogenesis. Some of the explants showed extensive callusing, which iwas friable and cream to light green. 2,4-D at $(0.452,1.130,2.26,4.52 \mu \mathrm{M} / \mathrm{l})$ in combination with BAP produced noticeable amounts of callus. The combination (BAP $13.32 \mu \mathrm{M} / 1+2,4$-D 0.452 $\mu \mathrm{M} / 1$ or $1.130 \mu \mathrm{M} / \mathrm{l}$ ) produced friable, extensive callus of light green colour and granular in its nature. Different stages of somatic embryos were noticed in these combinations. Similar types of observations were observed in TCL explants of Pelargonium (Gill et al. 1992), Heliconia psittacorum (Goh et al. 1995), Musa spp. (Nhut et al. 2003a), Manihot esculenta (Nhut et al. 2003b,c). In the present investigation similar observations were noticed in the nodal explants of $C$. spiralis (data not shown) and some other species of this family, such as Asclepias curassavica, (De Bagga et al. 1986; Pramanik et al. 1986) Calotropis gigantea (Roy and De 1990), Tylophora indica, (Sharma and Chandel 1992) Holostemma ada-kodien (Martin 2002, 2003).

The pre-existing hormone in the explant plays a crucial role in the stimulation of the shoot initials. We have noticed a problem of bleached shoots just because of the fast growth of the shoots. Moreover, some of the shoots necrosed and turned pale due to the presence of ethylene in the bottles/test tubes as in case of $C$. candelabrum (Beena et al. 2003). Chlorophyll formation rate is a bit slow, when compared to that of the formation of shoots, due to which the plants turned pale in their color. All the plants were pretreated in the medium containing auxins at various levels so that they all became a bit bulged in their girth by accumulating starch.

Some of the plants became non-responsive for a long time (Recalcitrants) as a result they died or did not grow for long time. These plants were used as explants for the tTCL culture. Recalcitrancy might be due to the production of free radicals, lipid peroxidases, and toxic, aldehydic lipid peroxidation products (Benson 2000) levels of these compounds vary in response to different tissue culture manipulations. Kaai et al. (2008) found a close relation between the recalcitrancy and the abscisic acid. However, recalcitrancy was found when plants were subcultured in vitro. It was defined as the inability of plant tissue culture to respond to in vitro manipulations. We have excised the explants from the either sides of the nodes, aiming at getting the meristematic tissue in sections where the metabolically and physiologically active tissues were expected. These tissues were stimulated when they were cultured on the medium suitable for the proliferation of callus and organogenesis finally becomes normal plant.

When TCL explants cultured on medium it may choose to show the multiple morphogenetic programmes like callusing, shoot regeneration, rooting, flowering, somatic embryogenesis etc., or individual morphogenetic programmes organogenesis as determined by the shoot apical meristem and as 
per the signal provided from the external plant growth regulators. Same results were observed in Saintpaulia ionantha, calluses, roots, somatic embryos, were achieved (Ohki 1994). Shoots and embryo like structures obtained from tTCLs of Amaranthus edulis when epidermis was cultured on the MS with a cytokinin (Bui et al. 1998). It is quite effective to use thin cell layers rather than using a complete node. TCLs have been successfully used in the micropropagation of Lilium longiflorum (Bui et al. 1999) and Oryza sativa (Nhut et al. 2001), including some recalcitrant ones, such as Lupinus spp. (Mulin and Bellio-Spataru 2000) and Spinacea oleracea (Leguillon et al. 2003).

The response of TCL explants excised from the nodes and inter nodes of recalcitrant plants was noted. The medium containing the low levels of 2,4-D had the less callusing ability, as the concentration increases, the callusing degree also increases up to $4.52 \mu \mathrm{M} / 1$. Whereas, IAA and IBA had no significant effect on callusing of the recalcitrants. Slight to high levels of callusing was noticed in the medium containing high levels of NAA. For further improvements, other factors were taken into account, such as hormonal and light pretreatments just like (Julliard et al. 1992, Nhut et al. 2000) the addition of $\mathrm{AgNO}_{3}$ (Aksaka-Kennedy et al. 2005) or of various sugars, but also more specific factors such as tTCLs explants thickness or position along the organ (Nhut et al. 2001).

The role of internal and external hormones on the organogenesis had notable effect in this particular investigation. As the concentration of the auxin (2,4-D) increases, the organogenic efficiency also increases, (Table 2). 2,4-D at $1.130 \mu \mathrm{M} / 1$ along with the BAP had optimum embryogenic callusing affinity wherein somatic embryos were observed (Fig. 1A). Homologous explants display discrepant differentiation in medium with deferent exogenous phytohormones. Exogenous hormones act as triggers in regulating explant differentiation, which in turn results in the production of extensive and friable callus. It was observed that the endogenous and exogenous hormonal supplies stimulated the bud initials to differentiate into either vegetative or floral buds.

Floral bud differentiation was initiated from explants of nodes in preflowering status when exogenous growth regulators IAA, NAA and IBA along with BAP were supplied in the medium. The TCL explants growing in the medium augmented with only auxins like NAA and IBA did not show any flowering, whereas the explants cultured on the medium supplemented with BAP along with IAA had a tremendous ability to induce and enlarge the flowers. The explants placed on the medium containing BAP $13.32 \mu \mathrm{M} / 1+$ IAA $5.77 \mu \mathrm{M} / 1$ showed enlarged flowers (Fig. 1D), whereas, IBA and NAA in combination with BAP had the ability to induce flower buds, but they did not mature properly and remained as such. In contrast, the explants on the medium with NAA+BA differentiated into floral buds, whereas IAA + BA were quite active in the 
vegetative bud formation. (Li Ying-Zhan and Han Bi-Wen 1995). In contrast with the findings by Van der Krieken et al. (1990) and Heylen (1991), endogenous contents in TCLs had significant role during floral bud differentiation and were significantly related to floral bud differentiation along with the external PGRs.

Table 2. Effect of BAP and different auxins concentrations on callusing of the recalcitrant thin cell layer of Ceropegia spiralis.

\begin{tabular}{|c|c|c|c|c|c|}
\hline \multirow{2}{*}{$\begin{array}{l}\mathrm{BAP} \\
\mu \mathrm{M} / 1\end{array}$} & \multicolumn{4}{|c|}{ Auxins in $\mu \mathrm{M} / \mathrm{l}$} & \multirow{2}{*}{$\begin{array}{l}\text { Degree of callusing } \\
\quad(\text { Mean } \pm S D)\end{array}$} \\
\hline & 2,4-D & IAA & IBA & NAA & \\
\hline 13.32 & 0.452 & & & & $1.67 \pm 0.29^{\mathrm{cd}}$ \\
\hline 13.32 & 1.130 & & & & $3.76 \pm 0.36^{a}$ \\
\hline 13.32 & 2.26 & & & & $3.70 \pm 0.44^{\mathrm{a}}$ \\
\hline 13.32 & 4.52 & & & & $3.88 \pm 0.29^{a}$ \\
\hline 13.32 & & 0.577 & & & $0.53 \pm 0.08^{\mathrm{d}}$ \\
\hline 13.32 & & 1.44 & & & $2.00 \pm 0.54^{c}$ \\
\hline 13.32 & & 2.88 & & & $2.06 \pm 0.53^{c}$ \\
\hline 13.32 & & 5.77 & & & $1.67 \pm 0.49 \mathrm{~cd}$ \\
\hline 13.32 & & & 0.49 & & $1.50 \pm 0.50^{\mathrm{cd}}$ \\
\hline 13.32 & & & 1.23 & & $1.92 \pm 0.21^{\mathrm{c}}$ \\
\hline 13.32 & & & 2.46 & & $1.95 \pm 0.42^{\mathrm{c}}$ \\
\hline 13.32 & & & 4.92 & & $1.72 \pm 0.40^{\mathrm{cd}}$ \\
\hline 13.32 & & & & 0.537 & $1.60 \pm 0.27^{\mathrm{cd}}$ \\
\hline 13.32 & & & & 1.342 & $2.14 \pm 0.28^{c}$ \\
\hline 13.32 & & & & 2.685 & $2.12 \pm 0.15^{c}$ \\
\hline 13.32 & & & & 5.37 & $2.84 \pm 0.64^{b}$ \\
\hline
\end{tabular}

Mean following by the same letter was not significantly different by Tukey test at $0.05 \%$ probability.

The source of the tTCLs was also a critical factor in our experiment. The tTCLs isolated from the nodal meristems responded well compared to any other explants, exhibited the highest shoot regeneration frequency. In our investigation, factors evaluated which had the influential role in morphogenesis.

This TCL technique could be used in the fundamental regeneration studies and for crop improvement through mutagenesis or transgenics in addition to being an efficient regeneration process (Teixeira da Silva and Fucai 2003) provided evidences of the capacity to efficiently produce non-chimeric transgenic plants using similar methods. Thus, tTCLs should provide good system for the study of fundamental and applied aspects of regeneration and transformation of this valuable, endangered, medicinal plant. 


\section{Acknowledgements}

The authors thank the authority of The Council of Scientific and Industrial Research (CSIR), New Delhi for providing financial assistance to carry our the present work.

\section{References}

Ahmedulla M and Nayar MP (1986) Endemic plants of the Indian region Peninsular India, Botanical Survey of India, Kolkata. Vol. 1.

Akasaka-Kennedy Y, Yoshida H and Takahata Y (2005) Efficient plant regeneration from leaves of rape seed (Brassica napus): the influence of $\mathrm{AgNO}_{3}$ and genotype. Plant Cell Rep. 24: 649-654.

Ansari MY (1984) Asclepiadaceae: Genus Ceropegia - Fascicles. In Flora of India. Botanical Survey of India, Calcutta 16: 1-34.

Beena MR and Martin KP (2003) In vitro propagation of the rare medicinal plant Ceropegia candelabrum L. through somatic embryogenesis, In vitro Cell Dev. Biol.-Plant. 39: 510-513.

Beena MR, Martin KP, Kirti PB and Hariharan M (2003) Rapid in vitro propagation of medicinally important Ceropegia candelabrum. Plant Cell Tiss. Org. Cult. 72: 285-289.

Benson EE, (2000) Special Symposium: In vitro plant recalcitrance, Do free radicals have a role in plant tissue culture recalcitrance. In Vitro Cell, Dev. Biol-Plant. 36: 163-170.

Britto SJ, Natarajan E and Arockiasamy DI (2003) In vitro flowering and shoot multiplication from nodal explants of Ceropegia bulbosa Roxb. var. bulbosa. Taiwania 48: 106-111.

Bruyns PV (2003) Three new succulent species of Apocynaceae (Asclepiadoideae) from Southern Africa. Kew Bull. 58: 427-429.

Bui VL, Nghieng thao DM, Jeanneau M, Sadik S, Tu S, Vidal J and Tran Thanh Van K, (1998). Rapid Plant Regeneration of a $C_{4}$ Dicot species: Amaranthus edulis. Plant Sci. 132: 4554.

Bui VL, Nhut DT and Tran Thanh Van K (1999) Plant production via Shoot regeneration from Thin cell layer Pseudo bulblet explants of Lilium longiflorum in vitro. CR Acad. Sci. Paris 322: 303-310.

Chopra RN, Nayar SL and Chopra IC (1956) Glossary of Indian medicinal plants CSIR. New Delhi.

De Bagga S, Chattopadhyay S, Kumar A, Ghosh KL, Datta K and Datta SK (1986) Differentiation of laticifer in Calotropis gigantea hormone and enzymatic regulation of tracheary elements in tissue culture of some plants. Int. Congr. Plant Tissue Cell Cult. 6 meet. 164 .

Gill R, Gerrath J and Saxena PK (1992) High frequency direct embryogenesis in thin layer cultures of hybrid seed geranium (Pelargonium). Can. J. Bot. 71: 408-413.

Goh CJ, Nathan MJ and Kumar PP (1995) Direct organogenesis and induction of morphogenetic callus through thin section culture of Heliconia psittacorum. Sci. Hort. 62: 113-120.

Goyal D and Bhadauria S (2006) In vitro propagation of Ceropegia bulbosa using nodal segments. Indian J. Biotech. 5: 565-568. 
Heylen C and Vendrg JC (1991) Further studies on the effect of different auxins and cytokinins on flower formation in the cell layers of Nicotiana tabacum. The effect of zeatin riboside. dihydrozeatin and dihydrozeatin riboside. Physiol. Plant. 83: 574-577.

Jain SK and Defillips RA (1991) Asclepiadaceae. In: Medicinal plants of India. Vol.1. Algonac, India.

Kaai F, Kawana Y and Sasamoto H (2008) The relation between recalcitrancy of a mangrove plant, Kandelia obovate, and high endogenous levels of Abscisic acid. Plant Cell Tissue Organ Cult. 94: 125-130.

Kirtikar KR and Basu BD (1935) Indian Medicinal Plants Vol. 3 pp. 1638 M/s Bishen Singh Mahendrapal, New Delhi, India.

Klimaszewska K and Keller WA (1985) High frequency plant regeneration from thin cell layer explants of Brassica napus. Plant Cell Tissue Organ Cult. 4: 183-197.

Leguillon S, Charles G and Branchard M (2003) Plant regeneration from thin cell layers in Spinacea oleracia. Plant Cell Tissue Organ Cult. 74: 257-265.

Li Ying-zhang and Han Bi-wen (1995) Changes of Endogenous IAA and Cytokinin contents during adventitious rooting formation in thin cell layer culture of Cichorium intybus explant. Plant Physiol. Communi. 31: 97-99.

Mabberely DJ (1987) The plant book. Cambridge University Press, Cambridge, pp. 114-115.

Madhav Gadgil (2004) ENVIS Technical Report No. 16, Environmental Information, Bangalore, http://www.ces.iisc.ernet.in/hpg/envis pp. 96-98.

Martin KP (2002) Rapid propagation of Holostemma ada-kodien Schult. a rare medicinal plant, though axillary bud multiplication and indirect organogenesis. Plant Cell Rep. 21: 112-117.

Martin KP (2003) Plant regeneration through somatic embryogenesis on Holostemma ada-kodien, a rare medicinal plant. Plant Cell Tissue Organ Cult. 72: 79-82.

Mulin M and Bellio-Spataru A (2000) Organogenesis from hypocotyl thin cell layers of Lupinus mutabilis and Lupinus albus. Plant Growth Regulators 30: 177-183.

Nadkarni KM (1976) Indian Materia Medica Vol.1 pp. 303-304 Popular Prakasha, Bombay, India.

Nayar MP and Sastry ARK (1987) Red Data Book of Indian plants Vol. 1 Botanical Survey of India, Calcutta. pp 170.

Nhut DT, Aswath CR, Teixeira da silva JA, Bui VL, Thorpe T and Tran Thanh Van K, (2003a) Tobacco thin cell layer morphogenesis. In: Thin cell layer culture system: regeneration and transformation applications. Nhut DT, Van Le B, Tran Thanh Van K, Thorpe T (eds) Kluwer Academic publishers, Dordrecht, The Netherlands, pp.65-134.

Nhut DT, Bui VL and Tran Thanh Van K (2000) Somatic embryogenesis and direct shoot regeneration of rice (Oryza sativa L.) using thin cell layers culture of apical meristematic Tissue. J. Plant Physiol. 157: 559-56.

Nhut DT, Bui VL and Tran Thanh Van K (2001) Manipulations of the Morphogenetic pathways of Lilium longifolium transverse thin cell layer explants by auxin and cytokinin. In Vitro Cell. Dev. Biol.-Plant. 37: 44-49.

Nhut DT, Teixeira da silva JA, Bui VL, Thorpe T and Tran Thanh Van K, (2003b) Woody plant micropropagation and morphogenesis by thin cell layers. In: Thin cell layer culture systems: regeneration and transformation applications. Nhut DT, Van Le B, Tran Thanh Van K, Thorpe T(eds) Kluwer Academic publishers, Dordrecht, The Netherlands, pp. 473493. 
Nhut DT, Teixeira da silva JA, Bui VL and Tran Thanh Van K (2003c) Thin cell layer(TCL) morphogenesis as a powerful tool in woody plant and fruit crop micropropagation and Biotechnology, Floral genetics and genetic transformation. In: Micropropagation of woody trees and fruits. Jain SM, Ishii K, (eds.). Kluwer Academic publishers, Dordrecht, The Netherlands, pp.783-814.

Nikam TD and Savant RS (2007) Callus culture and micropropagation of Ceropegia sahyadrica Ans. and Kulk.: An edible starchy tuberous rare asclepiad Indian. J. Plant Physiol. 12: 108114.

Ohki S (1994) Scanning Electron Microscopy of Shoot differentiation in vitro from leaf explants of the African Violet. Plant Cell Tiss. Org. Cult. 36: 157-162.

Patil VM (1998) Micropropagation of Ceropegia spp. In vitro Cell Dev. Biol. Plant. 34: 240-243.

Pramanik TK, De S, Dasgupta M and Datta SK (1986) Organ induced cardenolides biosynthesis in cultured tissues of Asclepias curassavica, Calotropis gigantea and Thevetia peruviana. int.Congr. Plant Cell Tiss. Org. Cult.. 6. meet 115.

Raghuramulu D and Pullaiah T (1999) In vitro propagation of Ceropegia bulbosa Roxb. from the seedling explants. In: Plant tissue culture and Biotechnology. Emerging trends. P.B. Kavikishore (Ed.). pp. 202-210.

Reddy CS, Reddy KN, Pattanaik C and Raju VS (2006) Ethnobotanical observations on some endemic plants of Eastern Ghats, India. http//:www.siu.edu.beb/leaflets/ ghats.htm

Roy AT and De DN (1990) Tissue culture and plant regeneration from immature embryo explants of Calotropis gigantea (Linn.) R.Br. Plant Cell Tiss. Org. Cult. 20: 229-233.

Sharma N and Chandel KPS (1992) Effect of Ascorbic acid on axillary shoot induction in Tylophora indica (Burm.f.) Merril Plant Cell Tiss. Org. Cult. 29:109-113.

Taxeira da silva JA and Fucai S (2003) Chrysanthemum organogenesis through thin cell layer technology and plant growth regulator control. Asian J. Plant Sci. 2: 505-514.

Van der Krieken WM. Croes AF, Smulders MJM and Wullems GJ (1990) Cytokinins and Flower bud formation in vitro in tobacco. Plant Physiol. 92: 565-569.

Venkateswara R, Shankara rao M and Vaidhyanathan CS (1987) Cryptosin - A new cardenolide in tissue culture and intact plant of Cryptolepis buchanani Roem and Schult. Plant Cell Rep. 6: 291-293. 